\title{
Forecasting the Agricultural Risk Insurance System Parameters
}

\author{
Mikhail Chernyakov ${ }^{1,}{ }^{*}$, Maria Chernyakova ${ }^{2}$, Irina Chernyakova ${ }^{1,2,}$, Sergey Gromov ${ }^{3}$ and \\ Saidmukhtor S. Mokhtarzada ${ }^{4}$ \\ ${ }^{1}$ Novosibirsk State Technical University, 630087, Novosibirsk, Russia \\ ${ }^{2}$ Siberian Institute of Management, 630102, Novosibirsk, Russia \\ ${ }^{3}$ Private institution "Rusatom-International Network", 119192, Moscow, Russia \\ ${ }^{4}$ Tajik state University of Commerce, Dushanbe, Republic of Tajikistan
}

\begin{abstract}
The current insurance market situation is characterised by a high degree of instability. Many factors influence insurance company premiums, including the number of contracts, the claim repayment ratio, capital structure, underwriting profitability and risk. The insurance sector serves as a protective barrier for the country's economy, defending it from various risks. At the same time, insurance company premiums are influenced by risks too. The number of research articles testifies to a stable interest in this problem. However, there is no technique for establishing the connection between the insurance premium and the many factors it is sensitive to. The article is devoted to the development of new models and, based on them, some digital technologies for forecasting agricultural insurance risk parameters. Based on a paradoxical theory of regulation and inno-diversification approach, an author's model was developed for forecasting activity. It was used to do calculations of the main indicators of the agiructural risk insurance system. As a result, it became possible to trace the main patterns and tendencies in the development of the agricultural risk insurance system in Russia. Special attention was paid to the period after 2017 when it started to stabilise and recover after the crises as a consequence of nonoptimal managerial solution as refers to the inclusion of the agricultural risk insurance system in the "single subsidy".
\end{abstract}

\section{Introduction}

Agriculture refers to a high-risk sector of the national economy, as it significantly depends on the conditions and final results of agricultural activities that are characterised by random factors, most often ecological and sanitary ones. Consequently, the utilisation of agricultural risk insurance programs occupies the determinant place in managing agrarian risk and minimising unforeseen losses. The stability and efficiency of the agricultural insurance system were proven by the many years of its use in the international insurance market. The idea of agricultural insurance is not new for the Russian Federation, and the government adopted some legislative and organisational and economic measures. However,

\footnotetext{
*Corresponding author: mkacadem@mail.ru
} 
because of some mistakes in making managerial solutions, the state-supported system of national agricultural insurance does not correspond now to the set tasks and requires improvements.

The financial stability of the insurance market is its main fundamental value as the ability of the insurer to fulfil their obligations in time and in full is significant for all market actors - from the insurer to the insurance supervision agencies. According to Ye.A. Konstantinova, O.Yu. Trezorova, maintenance of financial stability in an insurance company within the required range [1] is considered the factor creating the relations between economic entities and insurance companies. Problems of financial stability assessment in insurance organisations attract stable scientific and practical interest. Scientists discover various connections between the statutory regulation of the sector and insurers' financial soundness [2], between the capital structure and financial stability [3], between financial stability and risks [4], between risks and digitisation [5], between capital and risks [6], etc.

\section{Research Technique}

Building on the results of previous research, [1-6] the "inno-diversification approach technique [7-8] with the utilization of the methods of economic interpretation of findings, functional, comparative and static analysis" [6] became the basis of the prospective analysis.

It is advisable to develop a mathematical model for the assessment of the condition and the agricultural risk insurance system development with the application of prospective analysis of the paradoxical theory of regulation in the agro-industrial complex proposed by M.K. Chernyakov and M.M. Chernyakova and tested in the dairy sector [7-8]. To "develop the digital model, it is necessary to define the possible parameters characterizing agricultural risk insurance systems and approaches allowing the formalization of processes in this model. Twenty-one key index of the system covering all spheres of activity in agricultural insurance (Table 1) [9-12] was determined as parameters for the formalized model with the use of ranking and economic interpretation" [8].

Table 1. List of indices characterizing the agricultural risk insurance system.

\begin{tabular}{|c|l|}
\hline Designation & \\
\hline X1 & Period, years \\
\hline X2 & Volume of agro-industrial complex products, RUB bln \\
\hline X3 & Volume of crop products, RUB bln \\
\hline X4 & Volume of livestock products, RUB bln \\
\hline X5 & Share of insured areas, \% \\
\hline X6 & Share of insured animals, \% \\
\hline X7 & Insured cultivated/planting areas, mln hectares \\
\hline X8 & Insured animals, mln conditional heads \\
\hline X9 & Insurance premiums without state aid, RUB bln \\
\hline X10 & Insurance premiums with state aid, RUB bln \\
\hline X11 & $\begin{array}{l}\text { Average insurance premium for 1 contract of agricultural crop insurance with state } \\
\text { aid, RUB mln }\end{array}$ \\
\hline X12 & Average insurance premium for 1 contract of livestock insurance with state aid, \\
\hline
\end{tabular}




\begin{tabular}{|c|l|}
\hline X13 & $\begin{array}{l}\text { RUB mln } \\
\text { aid, RUB mln }\end{array}$ \\
\hline X14 & $\begin{array}{l}\text { Average amount insured for 1 contract of livestock insurance with state aid, RUB } \\
\text { mln }\end{array}$ \\
\hline X15 & $\begin{array}{l}\text { Portfolio of insurers - members of the National Association of Agriculture } \\
\text { Insurers (NAAI) for the agricultural crop insurance with state aid, thous. units }\end{array}$ \\
\hline X16 & $\begin{array}{l}\text { Portfolio of insurers - members of the National Association of Agriculture } \\
\text { Insurers (NAAI) for the livestock insurance with state aid, thous. units }\end{array}$ \\
\hline X17 & $\begin{array}{l}\text { Portfolio of insurers - members of the National Association of Agriculture } \\
\text { Insurers (NAAI) for the agricultural crop insurance with state aid, RUB bln }\end{array}$ \\
\hline X18 & $\begin{array}{l}\text { Portfolio of insurers - members of the National Association of Agriculture } \\
\text { Insurers (NAAI) for the livestock insurance with state aid, RUB bln }\end{array}$ \\
\hline X19 & Subsidies for insurance policy payment by agrarians, RUB mln \\
\hline X20 & State aid in the agricultural crop risk insurance segment, RUB mln \\
\hline X21 & State aid in the livestock risk insurance segment, RUB mln \\
\hline
\end{tabular}

The set task was to determine the influence of a period expressed in years (X1) on the main indices of the agricultural risk insurance system. The state aid system is of outstanding interest due to its dynamics and influence on the risk insurance results in the stock breeding and crop farming. It was also interesting to study the degrees of the impact on both absolute and relative parameters.

As the chosen indices of agricultural risk system have different dimensions and value, per recommendations of M.K. Chernyakov and M.M. Chernyakova [7-8], it is necessary to present all parameters in a depersonalized form, as a real number matrix (Table 2) [9-12] for prospective analysis.

Table 2. Depersonalised values of the indices characterizing the agricultural risk insurance system.

\begin{tabular}{|c|c|c|c|c|c|c|c|c|}
\hline $\mathrm{X} 1$ & 2012 & 2013 & 2014 & 2015 & 2016 & 2017 & 2018 & 2019 \\
\hline $\mathrm{X} 2$ & 3161 & 3458 & 4031 & 4794 & 5112 & 5110 & 5349 & 5908 \\
\hline $\mathrm{X} 3$ & 1492 & 1730 & 1987 & 2487 & 2710 & 2600 & 2756 & 3160 \\
\hline $\mathrm{X} 4$ & 1669 & 1728 & 2044 & 2307 & 2402 & 2510 & 2593 & 2748 \\
\hline $\mathrm{X} 5$ & 18.5 & 16.3 & 17.7 & 10.9 & 5 & 1.7 & 1.5 & 6.1 \\
\hline $\mathrm{X} 6$ & & 7 & 16.6 & 18 & 14.6 & 16.7 & 16.7 & 22.9 \\
\hline $\mathrm{X} 7$ & & & & & 4 & 1.3 & 1.2 & 6.8 \\
\hline $\mathrm{X} 8$ & & & & & 4.3 & 4.5 & 4.7 & 6.6 \\
\hline $\mathrm{X} 9$ & 2.6 & 2.2 & 2.1 & 1.3 & 1.3 & 1.5 & 1.7 & 1.3 \\
\hline $\mathrm{X} 10$ & 10.7 & 12.7 & 14.6 & 6.5 & 8.5 & 2.4 & 2 & 4.4 \\
\hline $\mathrm{X} 11$ & 1.4 & 1.7 & 2.6 & 3.9 & 5 & 3.1 & 2.3 & 1.5 \\
\hline $\mathrm{X} 12$ & & 1.6 & 2.1 & 2.6 & 2.8 & 2.3 & 3 & 3.8 \\
\hline $\mathrm{X} 13$ & 28.4 & 32.1 & 49 & 79.3 & 88.8 & 82.3 & 56.5 & 65.5 \\
\hline $\mathrm{X} 14$ & & 182.9 & 208 & 217.4 & 258.6 & 240.4 & 303.5 & 363.5 \\
\hline $\mathrm{X} 15$ & 3.99 & 3.97 & 2.44 & 1.2 & 1.6 & 0.88 & 0.43 & 1.86 \\
\hline
\end{tabular}




\begin{tabular}{|c|c|c|c|c|c|c|c|c|}
\hline $\mathrm{X} 16$ & & 0.181 & 0.285 & 0.34 & 0.359 & 0.187 & 0.337 & 0.346 \\
\hline $\mathrm{X} 17$ & 5.7 & 6.7 & 6.3 & 4.7 & 7.5 & 1.8 & 1 & 3.1 \\
\hline $\mathrm{X} 18$ & & 0.292 & 0.589 & 0.939 & 1.038 & 1.017 & 1.014 & 1.317 \\
\hline $\mathrm{X} 19$ & 4541 & 4674 & 5455 & 5363 & 2600 & 940 & 995 & 1944 \\
\hline $\mathrm{X} 20$ & 4541 & 4398 & 4997 & 4879 & 2275 & 529 & 492 & 1378 \\
\hline $\mathrm{X} 21$ & & 276 & 458 & 484 & 325 & 411 & 503 & 586 \\
\hline
\end{tabular}

\section{Research Results}

To determine a possible relation between the indices (Tables 1-2), correlation analysis was conducted allowing the detection of not only a relation between the key indices of the agricultural risk insurance system but also its proximity to the linear type. The result of the correlation analysis of 2013-2019 showed a wide range of differently directed correlation coefficients (R). Particularly big deviations are found in the crop production risk insurance. It is connected first of all with the adoption of Government Resolution No 1556 on 30 December 2016 on drastic changes in the principles of agricultural subsidy extension organization. As a result, some lines including agricultural insurance were included in the "single subsidy" according to which regions got the right to redistribute the government support funds at their discretion, which abruptly reduced the agricultural risk insurance support. This increased political risk led to the fast growth of the political and managerial risk influencing the ecological and economical risk, which in the long run impaired the volume of agricultural products, especially crops.

Only prompt amendments to the legislation on agricultural insurance in 2018 that came into force from 01 March 2019 and the adoption of the road-map for agricultural insurance development by the Ministry of Agriculture of Russia prevented the threatening collapse of the single agricultural risk insurance system in Russia. In 2019, due to the consolidation of efforts made by agricultural risk insurance system participants, it became possible to start a recovery growth allowing for the four-times increase of the insured crop acres. Agricultural insurance extent growth was noted in all federal districts. There was a factual system restart on a renewed legal framework, which opened prospects for extended use of insurance instruments for agricultural risks management. Starting from 2020, the "single subsidy" was cancelled, and funds for agricultural insurance were expressly accounted for the first time when calculating subsidies provided to the region for the support of agricultural production under the State Program of agriculture development.

The interrelations obtained as a result of the prospective analysis are the mathematical tool for the simulation model development. The digital technology algorithm for forecasting parameters of agricultural risk insurance system is given in Fig. 1. 


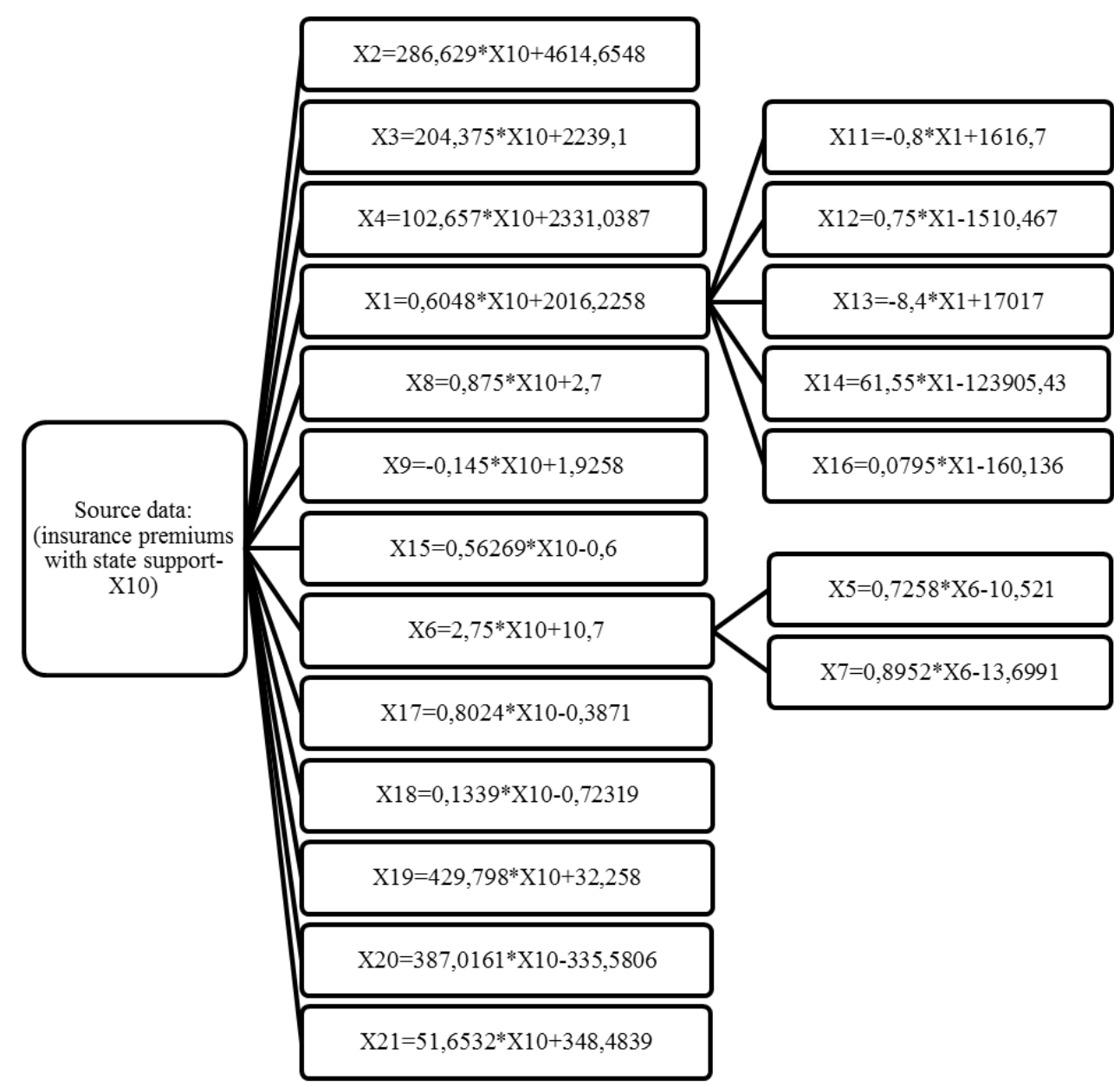

Fig. 1. Algorithm of the model of interaction of agricultural risk insurance system in the Russian Federation based on the insurance premium with state aid.

\section{Results and Discussion}

Digital technology built on the mathematical tool provided in the model algorithm can be used by all interested persons (governance bodies, NAAI, insurance companies, economic entities, etc.) to forecast parameters of the agricultural risk insurance system in the Russian Federation. Unlike the model for forecasting the influence of the time parameter, the developed model algorithm for the insurance premium with state aid turned out to be simpler, having a two-level structure. Besides, this parameter can be managed, and simulating modelling can be done with the help of the anticipated scenario calculation. An example of calculation for four possible scenarios is given in Table 3. All the calculated scenarios, except a pessimistic one, demonstrate the growth of most indices in the agricultural risk insurance system. Only the average insurance amount for 1 contract of insuring crops with state aid (X13) shows a decrease of approximately $25 \%$ of the expected scenario. But, due to its decrease, there is a growth of the insured cultivated areas by $65 \%$ and, as a consequence, a $15 \%$ increase in crop production is expected. 
Table 3. Forecasting of parameters characterizing the RF agricultural risk insurance system based on the insurance premium with state aid (X10)

\begin{tabular}{|c|c|c|c|c|c|}
\hline \multirow{2}{*}{ Mathematical model } & \multirow{2}{*}{$\begin{array}{c}\text { Actual } \\
\text { values for } \\
2019\end{array}$} & \multicolumn{4}{|c|}{ Scenarios for 2020} \\
\hline & & $\begin{array}{c}\text { Pessimisti } \\
\mathrm{c} \\
\end{array}$ & Probable & Expected & Optimistic \\
\hline \multicolumn{6}{|l|}{$1^{\text {st }}$ level based on X10 } \\
\hline $\mathrm{X} 10=\mathrm{X} 10$ & 4.4 & 4.40 & 5.13 & 6.24 & 7.90 \\
\hline$X 1=0.6048 * X 10+2016.2258$ & 2019 & 2019 & 2019 & 2020 & 2021 \\
\hline $\mathrm{X} 2=286.629 * \mathrm{X} 10+4614.6548$ & 5588.1 & 5875.82 & 6085.06 & 6403.22 & 6879.02 \\
\hline$X 3=204.375 * X 10+2239.1$ & 2912.5 & 3138.35 & 3287.54 & 3514.40 & 3853.66 \\
\hline $\mathrm{X} 4=102.657 * \mathrm{X} 10+2331.0387$ & 2675.6 & 2782.73 & 2857.67 & 2971.62 & 3142.03 \\
\hline $\mathrm{X} 6=2.75 * \mathrm{X} 10+10.7$ & 22.9 & 22.80 & 24.81 & 27.86 & 32.43 \\
\hline $\mathrm{X} 8=0.875 * \mathrm{X} 10+2.7$ & 6.6 & 6.55 & 7.19 & 8.16 & 9.61 \\
\hline $\mathrm{X} 9=-0.145 * \mathrm{X} 10+1.9258$ & 1.3 & 1.29 & 1.18 & 1.02 & 0.78 \\
\hline $\mathrm{X} 15=0.56269 * \mathrm{X} 10-0.621$ & 1.86 & 1.85 & 2.27 & 2.89 & 3.82 \\
\hline $\mathrm{X} 17=0.8024 * \mathrm{X} 10-0.4345$ & 3.1 & 3.10 & 3.68 & 4.57 & 5.90 \\
\hline $\mathrm{X} 18=0.1339 * \mathrm{X} 10+0.72319$ & 1.317 & 1.31 & 1.41 & 1.56 & 1.78 \\
\hline $\mathrm{X} 19=429.798 * \mathrm{X} 10+32.258$ & 1944 & 1923.37 & 2244.43 & 2725.20 & 3444.19 \\
\hline $\mathrm{X} 20=387.0161 * \mathrm{X} 10-335.5806$ & 1378 & 1367.29 & 1649.81 & 2079.40 & 2721.85 \\
\hline $\mathrm{X} 21=51.6532 * \mathrm{X} 10+348.4839$ & 586 & 575.76 & 613.46 & 670.80 & 756.54 \\
\hline \multicolumn{6}{|l|}{$2^{\text {nd }}$ level based on X1 } \\
\hline $\mathrm{X} 11=-0.8 * \mathrm{X} 1+1616.7$ & 1.5 & 1.59 & 1.24 & 1.64 & 2.75 \\
\hline $\mathrm{X} 12=0.75 * \mathrm{X} 1-1510.467$ & 3.8 & 3.70 & 4.03 & 4.53 & 5.29 \\
\hline $\mathrm{X} 13=-8.4 * \mathrm{X} 1+17017$ & 65.5 & 58.35 & 54.64 & 49.00 & 40.57 \\
\hline $\mathrm{X} 14=61.55 * \mathrm{X} 1-123905.43$ & 363.5 & 357.06 & 384.23 & 425.55 & 487.35 \\
\hline $\mathrm{X} 16=0.0795 * \mathrm{X} 1-160.136$ & 0.346 & 0.37 & 0.40 & 0.45 & 0.53 \\
\hline \multicolumn{6}{|l|}{$2^{\text {nd }}$ level based on X6 } \\
\hline $\mathrm{X} 5=0.7258 * \mathrm{X} 6-10.521$ & 6.1 & 6.03 & 7.48 & 9.70 & 13.01 \\
\hline$X 7=0.8952 * X 6-13.6991$ & 6.8 & 6.71 & 8.51 & 11.24 & 15.33 \\
\hline
\end{tabular}

Unlike the model for forecasting based on the time influence [7], the developed model algorithm based on the insurance premium with state aid is simple, with a two-level structure. In addition, this parameter can be managed, and there is a possibility of simulation modelling using the forecast scenario calculation. An example of the calculation of four possible scenarios is given in Table 3. All calculation scenarios, except the pessimistic one, demonstrate growth in most indices of the agricultural risk insurance system. Only the average insurance amount for one crop insurance contract with state aid (X13) shows a decrease - approximately $25 \%$ for the expected scenario. But, due to its decrease, there is a growth of the cultivated areas by $65 \%$ and, as a result, a $15 \%$ increase in the crop products is expected. 
A small but stable growth trend is shown by the risk insurance system indices in the stock breeding complex (on average by 15\%), though it is $6 \%$ lower than during the previous years. It should be noted that all indices of the risk insurance system in the stock breeding complex interact with the regulating parameter at the first level of direct impact, and most crop parameters - at the second and third levels of the indirect impact.

The trend of agricultural product volume growth in the Russian Federation by $12 \%$ will be preserved, including the $9 \%$ growth rates in the stock breeding and $16.7 \%$ in crop farming, as well as the insurance premium with state aid - by $16.6 \%$. Without state aid, it will remain at the previous level.

\section{Conclusion}

The digital technique developed with the help of a mathematical tool and the author's model algorithm can be used by all interested persons (governance bodies, NAAI, insurance companies, economic entities, etc.) to forecast parameters of the agricultural risk insurance system in the Russian Federation.

The reported study was funded by RFBR according to research project No. 20-310-90002.

\section{References}

1. E.A. Konstantinova, O.Yu. Trezorova, Problems and Prospects of Insurance Development in Russia, Vestnik of Economy and Management Institute at Yaroslav Mudry Novgorod State University, 2(21), 47-54 (2016).

2. N. Gavira-Durón, D. Mayorga-Serna, \& A. Bagatella-Osorio, The financial impact of the implementation of Solvency II on the Mexican insurance sector, The Geneva Papers on Risk and Insurance - Issues and Practice, (2020) DOI: https://doi.org/10.1057/s41288-020-00196-1

3. M. Rubio-Misas, Ownership structure and financial stability: Evidence from Takaful and conventional insurance firms, Pacific-Basin Finance Journal, 62, 101355. (2020) DOI: https://doi.org/10.1016/j.pacfin.2020.101355

4. I. Moreno, P. Parrado-Martinez, A. Trujillo-Ponce, Economic crisis and determinants of solvency in the insurance sector: new evidence from Spain. Accounting and Finance, 60(3), 2965-2994 (2020) DOI: https://doi.org/10.1111/acfi.12422

5. D.V. Bryzgalov, Y.V. Gryzenkova, , \& A.A. Tsyganov, Prospects for Digitalization of the Insurance Business in Russia, Financial Journal, 12(3), 76-90 (2020) DOI: https://doi.org/10.31107/2075-1990-2020-3-76-90

6. M. Dacorogna, A change of paradigm for the insurance industry, Annals of Actuarial Science, 12(2), 211-232 (2018) DOI: https://doi.org/10.1017/S1748499518000040

7. M.K. Chernyakov, M.M. Chernyakova, A system-inno-diversified approach to the development of technologies for the effective transformation of organisations of the agro-industrial complex into a digital economy. IOP Conference Series: Materials Science and Engineering, 1019. Art. 012026 (11 p.). (2021) DOI: 10.1088/1757899X/1019/1/012026.

8. M.K. Chernyakov, M.M. Chernyakova, Innodiversification model of the digital economy of the agricultural sector [Electronic resource]. Advances in Social Science, Education and Humanities Research, 240, 562-567, Mode of access: https://www.atlantis-press.com/proceedings/sicni-18/55911909. - Title from screen (2019) DOI: 10.2991/sicni-18.2019.114. 
9. K.D. Bizhdov, NSA. Annual Report of 2019. Agricultural Insurance: Growth Path, 62 (2020)

10. K.D. Bizhdov, NSA. Annual Report of 2018. Agricultural Insurance: New Horizons, 54 (2019)

11. K.D. Bizhdov, NSA. Annual Report of 2017. Agricultural Insurance for Russia, 58 (2018)

12. Main RF Agriculture Indices in 2019, Meatinfo URL: https://meatinfo.ru/news/osnovnie-pokazateli-selskogo-hozyaystva-rf-v-2019-godu407266 (2020) 